\title{
Perjalanan Karir Kesenimanan Siti Chairani Proehoeman Sebagai Penyanyi Soprano (Sebuah Biografi)
}

\author{
Ofa Yutri Kumala ${ }^{1)}$, Martarosa $^{2)}$, Nursyirwan ${ }^{3)}$ \\ ${ }^{1) 23)}$ Program Pascasarjana, Institut Seni Indonesia (ISI) Padangpanjang \\ Jl. Bahder Johan Guguk Malintang, Padang Panjang-Kota Padang Panjang, Sumatera Barat 27118 \\ Email :yutri1993@gmail.com ${ }^{1)}$, marta23365rosa@gmail.com ${ }^{2)}$, doctornursyirwanmsn.ugm2011@ @mail.com ${ }^{31}$
}

\begin{abstract}
This research, is the career journey of Siti Chairani Proehoeman as a soprano who has taken part in various countries, and is a great teacher who is a role model for every student who specializes in studying in the field of sound art. Siti Chairani Prohoeman is an Indonesian citizen who is very influential in Malaysia, he created a movement about vocals in Malaysia, great enthusiasm Siti Chairani Proehoeman has made vocals a culture for Malaysia. The names of the countries that Siti Chairani Proehoeman often performed at concerts, operas and recitals are in Italy, Germany, the Netherlands, France, Finland, USA, Japan, South Korea, Thailand, Singapore, Malaysia, Indonesia. Siti Chairani Proehoeman already has several serial albums and her professional career is a Classical / Opera singer (Soprano). The factors of Siti Chairani Proehoeman became a famous soprano in various countries, namely family background, habits, environment and education. This study discusses Siti Chairani Proehoeman's career as a soprano in a biographical form. In this case the history of Siti Chairani Proehoeman's career as a soprano based on data, sources, informants and all matters relating to the life history of an artist. This research method, analytic description, case study, observer participation. The results showed that, in the practice of Siti Chairani Proehoeman's life based on a musicalological perspective and assisted through historical and biographical reviews, Siti Chairani Proehoeman's position was a famous soprano.
\end{abstract}

Keywords : soprano, vocal art, singer and biography, Siti Chairani Proehoeman

\begin{abstract}
ABSTRAK
Penelitian ini, merupakan perjalanan karir kesenimanan Siti Chairani Proehoeman sebagai seorang soprano yang telah berkiprah di berbagai negara, dan merupakan guru besar yang menjadi panutan bagi setiap muridnya yang khusus belajar di bidang seni suara. Siti Chairani Prohoeman adalah seorang warga negara Indonesia yang sangat berpengaruh besar di Malaysia, beliau menciptakan pergerakan movement tentang vokal di Malaysia, semangat yang besar Siti Chairani Proehoeman telah menjadikan vokal sebagai kebudayaan bagi negara Malaysia. Nama negara-negara yang sering dilakukan Siti Chairani Proehoeman pada konser, opera dan recital adalah di Italia, Jerman, Belanda, Perancis, Firlandia, USA, Jepang, Korea Selatan, Thailand, Singapura, Malaysia, Indonesia. Siti Chairani Proehoeman sudah mempunyai beberapa album seriosa dan karir profesional beliau adalah seorang penyanyi Klasik/Opera (Soprano). Adapun faktor-faktor Siti Chairani Proehoeman menjadi soprano terkenal diberbagai negara yaitu faktor latar belakang keluarga, kebiasaan, lingkungan dan pendidikan. Penelitian ini membahas perjalanan karir Siti Chairani Proehoeman sebagai penyanyi soprano dalam bentuk biografi. Dalam hal ini sejarah perjalanan karir Siti Chairani Proehoeman sebagai penyanyi soprano berdasarkan data-data, sumber, informan dan segala hal yang berkaitan dengan sejarah kehidupan seorang seniman. Metode penelitian ini, deskripsi analitik, studi kasus, partisipasi observer. Hasil penelitian menunjukkan bahwa, dalam praktik kehidupan Siti Chairani Proehoeman berdasarkan pandangan musikologis dan dibantu lewat tinjauan sejarah serta biografi maka posisi Siti Chairani Proehoeman adalah penyanyi soprano terkenal.
\end{abstract}

Kata kunci: soprano, seni suara, penyanyi dan biografi, Siti Chairani Proehoeman 


\section{Pendahuluan}

Pengaplikasian musik tidak terlepas dari penikmat musik, instrument, pemain, tempat pertunjukan, bentuk musik, zaman atau sejarah musik yang ikut mempengaruhi perkembangan musik dan karya musik. Karya-karya musik yang dimainkan dan akan disajikan dalam bentuk pertunjukan musik baik dalam bentuk instrument vokal, gitar, piano violin dan sebagainya. Penyajian musik atau pertunjukan musik adalah suatu penyajian fenomena bunyi yang disajikan dalam bentuk musik yang berkualitas untuk dapat didengar dan dinikmati oleh manusia. Siti Chairani Prohoeman adalah anak dari Februman Prohoeman dan Rebecca Prohoeman yang kedua orang tuanya berasal dari Bonjol, Pasaman Timur, Sumatera Barat. Siti Chairani Prohoeman lahir di Jakarta, 31 Oktober 1949 di RS Budi Kemulyaan, Jakarta. Kehidupan Siti Chairani Proehoeman sejak umur 17 tahun, lebih banyak dihabiskan di luar negeri dari pada di Indonesia (Siti Chairani Proehoeman, wawancara 19 November 2017 di Jl. Kampung Talang no 15 Ganggo Hilia, Bonjol Pasaman).

Siti Chairani Proehoeman termasuk seorang yang jenius memiliki wawasan sangat luas di bidang ideologi, filsafat, bidang seni rupa, dan seni pertunjukan, sesuai dengan lingkungan dan latar belakang keluarganya yang berpendidikan tinggi. seni pertunjukan yang dikuasai Siti Chairani Proehoeman adalah seni musik, terutama instrument vokal. Menurut Yoesbar Djaelani seorang komponis musik Indonesia yang merupakan rekan kerja dalam bermusik, Siti Chairani Proehoeman adalah seorang yang disiplin dalam bermusik, kedisiplinan adalah hal yang utama baginya. Siti Chairani Proehoeman sangat menguasai teknik vokal seriosa (Yoesbar Djailani, wawancara 15 November 2017 di Padangpanjang).

Seriosa di Indonesia adalah salah satu dari tiga jenis musik "modern" Indonesia, yang setiap tahunnya sejak 1951 dilombakan dalam kegiatan yang disebut dengan bintang radio. Kedua jenis lainnya dalam lomba itu adalah hiburan dan keroncong, ketiganya, adalah bagian dari musik Barat. Jelas seriosa merupakan wadah musik vokal. Dalam acuan di atas seriosa adalah wadah tentang pelaksanaan interpretative seorang vokalis terhadap seni suara, seni yang dilaksanakan oleh mulutnya atas kumpulan kata-kata dalam sebuah lagu. (Katamsi, 2011). Kehadiran Siti Chairani Proehoeman sebagai salah satu tokoh seriosa di Indonesia dan luar negeri sudah berbagai pertunjukan yang telah dilakukannya baik di Indonesia maupun di luar Negara Indonesia. Siti Chairani Proehoeman sudah mempunyai beberapa album seriosa dan karir profesional beliau adalah seorang penyanyi Klasik/Opera (Soprano). Soprano adalah penyanyi suara tertinggi dalam klasifikasi vokal di dalam budaya klasik Barat. Istilah ini berasal dari bahasa Italia 'sopra' yang berarti melampaui dan juga bahasa latin 'supra' yang berarti super (Id.m.wikipedia,org/wiki/sopran).

Penyajian konser recital, dan opera banyak dilakukan Siti Chairani Proehoeman dari tahun 1968 sampai sekarang. Nama negara-negara yang sering dilakukan Siti Chairani Proehoeman pada konser, opera dan recital adalah di Italia, Jerman, Belanda, Perancis, Firlandia, USA, Jepang, Korea Selatan, Thailand, Singapura, Malaysia, Indonesia. Daftar rincian dan lampiran penyajian akan di teliti lebih lanjut. Siti Chairani Prhohoeman mempunyai tugas resmi diluar negeri salah satunya Memimpin "Misi The National Choir of Malaysia" sebagai direktur dan vokal master ke Childrens's World Festival di Nagoya dan Fukuoka, Jepang, 1990 dan banyak lagi kegiatan vokal master yang dipimpin oleh Siti Chairani Proehoeman (Chairani: 2006).

Siti Chairani Prohoeman adalah seorang warga negara Indonesia yang sangat berpengaruh besar di Malaysia, beliau menciptakan pergerakan movement tentang vokal di Malaysia, semangat yang besar Siti Chairani Proehoeman telah menjadikan vokal sebagai kebudayaan bagi negara Malaysia. Siti Chairani Prohoeman menyanyikan pertama kali membawakan lagu opera dengan bahasa Melayu di Malaysia. Menurut Normah Nurdin, Siti Chairani Proehoeman adalah seorang yang sangat mencintai semua kosmos di muka bumi ini, sangat cinta masyarakat Indonesia Minang khususnya. Normah Nurdin mengenal sosok Siti Chairani Prohoeman sangat berpengaruh besar pada kemahiran seni suara di Malaysia (Norma Nurdin, wawncara 18 Januari 2018 di Padangpanjang,).

Siti Chairani Proehoeman sangat terkenal di luar negara Indonesia, beliau adalah seorang guru besar yang sangat berpengalaman tinggi dibidang seni suara (Nurkholis, wawancara 16 Februari 2018 di Padangpanjang). Siti Chairani Proehoeman juga mendapat gelar Profesor di negeri Malaysia, selain itu beliau merupakan salah seorang soprano yang sering konser di acara-acara besar di berbagai negara baik sebagai penyanyi art song, recital bahkan opera, banyak opera yang di kuasai oleh Siti Chairani Proehoeman dan tampil di luar negara Indonesia, tetapi di negara Indonesia tidak begitu banyak mendengar nama besar Siti Chairani Proehoeman, walaupun beliau telah berkiprah di luar negara Indonesia dan selalu memperkenalkan dan menyajikan repertoar seriosa Indonesia di negara lain, tetapi tidak banyak yang mengetahui bahwa seorang Siti Chairani Proehoeman adalah seorang soprano yang sangat besar pengaruhnya di dalam dunia vokal dan sudah diakui oleh negar lain.

\section{Pembahasan}

Penelitian ini membahas perjalanan karir Siti Chairani Proehoeman sebagai penyanyi soprano dalam bentuk biografi.Biografi adalah kisah atau keterangan tentang kehidupan seseorang. Biografi lebih kompleks dari pada sekedar daftar tanggal lahir atau mati, dan data-data pekerjaan seseorang. Biografi juga bercerita tentang perasaan yang terlibat dalam mengalami kejadian-kejadian tersebut, dalam biografi dijelaskan secara lengkap kehidupan seseorang tokoh sejak kecil sampai tua, bahkan sampai meninggal dunia. Semua 
jasa, karya dan segala hal dihasilkan atau dilakukan oleh seseorang tokoh tersebut (www.zonasisw.com,diakses 7 Juli 2018).

Dalam hal ini sejarah perjalanan karir Siti Chairani Proehoeman sebagai penyanyi soprano berdasarkan datadata, sumber, informan dan segala hal yang berkaitan dengan sejarah kehidupan seorang seniman, menurut Barzun dan Graff, 1970 sejarah adalah hasil rekonstuksi sejarawan mengenai pengalaman masa lampau manusia berdasarkan atas sumber-sumber tercatat (tertulis,lisan, karya-karya seni) atau relik-relik (Sjamsuddin, 1996:283).

\section{A. Perjalanan karir Siti Chairani Proehoeman Sebagai Penyanyi Soprano dan Pen}

Pada tahun 80an Siti Chairani Kembali ke Asia yaitu di negara Malaysia, dan pada saat itu keluarga Siti Chairani Proehoeman menetap di sana, pada saat itu orang tuanya berteman dengan pejabat-pejabat tinggi di Malaysia. Dan pada suatu hari orang tua Siti Chairani Proehoeman mempunyai kenalalan yaitu Rektor ITM (Institut Teknologi Mara) dan mempunyai anak yang baru lulus pada tahun 85 lulusan luar negeri dan kembali ke Malaysia dan dia pada saat itu kenalannya mendengar bahwa Siti Chairani Proehoeman adalah seorang lulusan dari Eropa (lulusan luar negeri) bidang seni suara, dan langsung memintanya untuk bergabung dengan ITM untuk bergabung sebagai pronir/pelopor industri vokal, pendidikan formal vocal education (Siti Chairani Proehoeman, wawancara 5 agustus 2018, di Jl. Kampung Talang no 15 Ganggo Hilia, Bonjol Pasaman).

Pada tahum 1987 Siti Chairani Proehoeman langsung bekerja dengan ITM dan sekarang berganti nama dengan UiTM (Universitas Teknologi Mara). Saat mengajar di ITM para mahasiswa sangat beruntung dan bisa belajar apa yang tidak didapatnya seperti bahasa asing, sejarah musik dan sebagainya karena di ITM pada saat itu sangat kekurangan dosen untuk mengajar mata kuliah. Di ITM Siti Chairani Proehoeman banyak bekerja, karena mahasiswa yang ada di ITM sangat sedikit dan tiba-tiba saat ada Dosen baru Siti Chairani Proehoeman mengajar di ITM banyak mahsiswa baru yang masuk untuk belajar di ITM karena mereka mengetahui ada Dosen lulusan luar negeri yang mengajar di ITM dan mereka dapat pengetahuan dan belajar tentang mata kuliah seni suara. Siti Chairani Proehoeman banyak mendapat tawaran bernyanyi di mana-mana, dan mahasiswanya mayoritas menjadi orang terkenal, baik dibidang seni suara professional, akademis, pemerintahan, diplomat berbagai bagai bidang dan pada umumnya semuanya sukses dan berhasil dan menjadi penyanyi ternama. (Siti Chairani Proehoeman, wawancara 5 agustus 2018, di Jl. Kampung Talang no 15 Ganggo Hilia, Bonjol Pasaman).

1. Sebagai Penyanyi Soprano

Saat Siti Chairani Proehoeman pindah ke Asia khususnya di Malaysia mendapat tawaran bernyanyi di berbagai konser-konser, recital dan musik kamar di Malaysia, sejak mengajar di ITM semua orang Malaysia mengenal sosok Siti Chairani Proehoeman. Menurut Normah Nurdin Siti Chairani proehoeman terkenal karena telah menciptakan pergerakan atau movement tentang pentingnya belajar bernyanyi di Malaysia. Karena sebelum itu belum ada orang yang mampu untuk melakukan hal tersebut di Malaysia, orang Malaysia sangat beruntung dengan kehadiaran Siti Chairani Proehoeman (Norma Nurdin, wawncara 18 Januari 2018 di Padangpanjang).

2. Aktifitas Pertunjukan Yang Pernah Dilaksanakan

Berbagai pertunjukan yang pernah dilakukan Siti Chairani Proehoeman, melalui wawancara bersama pianisnya Muzafar Abdullah, beliau selalu konser bersama dengan Siti Chairani Proehoeman dan baginya, beliau adalah pasangan duo musik yang paling sesuai dengannya, Muzafar Abdullah dan Siti Chairani Proehoeman pernah konser di Malaysia, Indonesia, Perancis, Finlandia dan Republik Czech. Saat penampilan lagu seriosa di Finlandia Muzafar Abdullah merupakan pianis Siti Chairani Proehoeman, Lagu seriosa Indonesia adalah salah satu repertoire favorit Muzaffar Abdullah, Penonton di Europe tidak mengetahui repertoire ini dan bila ditampilkan di konser penonton curious dan meminatinya. Selain sebagai seorang soprano Siti Chairani Proehoeman menjadi seorang guru Siti Chairani Proehoeman adalah pedagog berfilosofi dan berdedikasi (Wawancara Muzafar Abdullah, 23 Juli 2018 di media sosial facebook di Perancis-Indonesia).

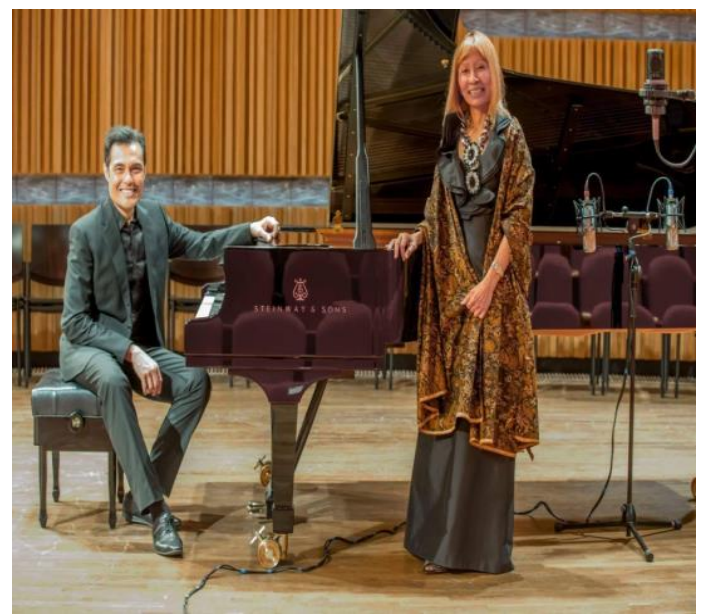

Gambar 1. Sebelum konserdi eropa

(Dokumentasi: Muzafar Abdullah repro oleh Ofa Yutri Kumala, 23 Juli 2018)

Saat wawancara dengan Irina Titova satu penampilan yang menonjol dalam ingatannya di mana saat berkolaborasi bersama, ketika itu adalah sebuah acara untuk penghormatan kepada P.Ramlee seorang aktor Melayu, Irinna ingin mendapatkan lebih banyak kesempatan untuk tampil bersama Siti Chairani Proehoeman seperti itu karena itu adalah pengalaman yang menyenangkan baginya. Perasaannya ketika tampil bersama dengan Siti Chairani Proehoeman selama berkolaborasi saat konser merasa sangat nyaman bekerja dengan Prof Siti Chairani Proehoeman, karena profesionalismenya. Mudah untuk mencapai keselarasan musik dan hal lain yang diperlukan untuk membuat 
pertunjukan itu sukses (wawancara, Irina Titova 23 Juli 2018 di media sosial WA (Whats App) di RusiaIndonesia)

Berdasarkan hasil wawancara yang telah dilakukan bersama Ayoub Ibrahim Ada cukup banyak kesempatannya tampil bersama Siti Chairani Proehoeman selama masa kuliah atau masa belajar, beliau adalah orang yang selalu mendorong seseorang untuk terus berkarya dan menyingkirkan perasaan gugup dan mengatasi rasa rendah diri seseorang (Membangkitkan Percaya diri). Beliau juga seorang pelatih vokal untuk paduan suara fakultas musik, dan ansambel penyanyi dan kami biasanya mendapatkan undangan dalam jumlah yang banyak untuk tampil Bersama beliau termasuk pertunjukan umum, resital dan bahkan di tv. Kemudian sebagai rekan kerja ia akan mengatur dan menjadi direktur artistik untuk mahasiswa dan fakultas ASWARA, seperti malam klasik, resital suara dan sebagainya (Wawancara Ayoub Ibrahim, 3 Agustus 2018 media sosial WA (Whats App) di Malaysia-Indonesia).

3. Beberapa Pendapat dan Komentar Mengenai Pertunjukan Vokal Siti Chairani Proehoeman.

Menurut Muzafar Abdullah Sosok musikalitas Siti Chairani Proehoeman sangat tinggi dan disertai dengan pengalaman yang luas. Karakter Siti Chairani Proehoeman adalah positif dan aktif, beliau suka membaca dan ingin mengetahui (sikap curious) dan ini membuatnya semakin penuh dengan pengetahuan dan pengalaman. Frasa Siti Chairani Proehoeman cocok dengan frasa repertoire yang dipersembahkan, kerena musikalitas dan pemahaaman, ucapan lirik-lirik Siti Chairani Proehoeman dari repertoire yang berbeda bahasa ucapan bahasa-bahasa asing itu sempurna jelas dan sangat bagus dalam setiap bahasa. (Wawancara Muzafar Abdullah, 23 Juli 2018 di media sosial facebook di Perancis-Indonesia).

Menurut Irina Titova yang merupakan sebagai seorang pianis dari Rusia pandangannya terhadap Siti Chairani Proehoeman sebagai penyanyi sopran sebagai pemain klasik saat wawancara beliau mengungkapkan bahwa Sulit menjelaskan pendapatnya ke dalam katakata karena Irina Titova telah mengetahui dan mengalami sendiri profesionalisme seorang Siti Chairani Proehoeman dan pengetahuannya yang dalam di semua aspek. beliau juga berpikir pertunjukan yang telah dia jalani memberikan indikasi yang jelas tentang betapa luar biasanya dia tidak hanya sebagai sopran tapi juga sebagai sorang sosok yang patut di tiru dan di contoh(wawancara, Irina Titova 23 Juli 2018 di media sosial WA (Whats App) di Rusia-Indonesia).

4. Berkarir sebagai seorang pendidik

Tidak hanya sebagai seorang penyanyi sopran yang selalu melakukan konser, tetapi Siti Chairani Proehoeman juga nerupakan seorang pendidik dan mengajar Vokal diberbgai Universitas di Malaysia dan STSI Padangnjang, Siti Chairani Proehoeman mengajar vokal sama dengan gurunya saat belajar di Eropa semua itu diterapkan kebali kepada murid-murid yang belajar dengannya dengan cara yang telah dipelajari dari gurugurunya saat kuliah di Eropa.

5. Cara Mengajar Vocal

Saaat pindah ke Malaysia Siti Chairani Proehoeman mulai mengajar di ITM dan berbagai universitas seini yang ada di Malaysia ini beberapa penjelsan dari hasil wawancara dari berbagai murid Siti Chairani Proehoeman dalam perjalanan karir Siti Chairani Proehoeman saat berkarir sebagai seorang pendidik.

Menurut Jamilah, melalui ilmu yang Jamilah data melalui Prof Siti, beliau sangat menekankan kepentingan frasa yang betul dalam nyanyian. Begitu juga interpretasi dan ekspresi. Seperti yang tersedia, lagu-lagu klasikal terdiri dari pada berbagai zaman atau era, di mana setiap zaman tersebut mempunyai frasa yang berbeda. Contohnya perbedaan frasa lagu-lagu zaman Barok dengan Romantik. Kedua-duanya berbeda dari segi frasa maupun interpretasi dan ekspresi. Selanjutnya lagu-lagu klasikal terdiri dari bahasa yang berbeda. Kesalahan dalam menyanyikan frasa kata yang tidak betul harus dilelakkan. Interpretasi juga ditekankan dalam pengajaran beliau. Hal ini demikian kerana interpretasi yang salah mampu merusak kualitas nyanyian di mana keaslian aliran lagu menjadi berubah. Interpretasi juga berbeza dari zaman ke zaman (Jamilah Binti Abu Bakar, wawancara 17 Juni 2018 di media sosial WA (Whats App) di Malaysia-Indonesia).

Azizzil Haqim pernah mempunyai guru vokal selain Siti Chairani (Sebelum berguru dengan Siti Chairani). Teknik serta kaedah pengajaran dan pembelajaran Siti Chairani lebih teratur serta lebih mudah di fahami. Itu disebabkan oleh pengalaman serta kemahiran yang tinggi, yang ada pada beliau. Malah beliau merupakan seorang Doktor ketika beliau mendidik Azizzil Haqim. Tentu sekali cara serta teknik mengajar beliau amatlah baik dan teratur. Salah satu perubahan yang ketara pada dirinya setelah berguru dengan beliau adalah dari segi 'range' kerana beliau telah banyak melatih Azzizul Haqim menyanyikan high not dengan baik, dan intonasi suara. Suara saya jauh lebih bulat dan ton suara lebih ringan ketika menyanyi. (Azzizul Hakim, wawancara 28 Juni 2018 di media sosial WA (Whats App) di Malaysia-Indonesia)

Berdasarkan wawancara yang didapat dari Natasha Sass dia berfikir pikir ketika belajar dengan Siti Chairani Proehoeman dan menjadi muridnya, dia merasa Siti Chairani Proehoeman memiliki pendengaran dan telinga yang sangat baik dalam membedakan suara dari penyanyi yang berbeda dan tidak berharap seorang penyanyi bisa menjadi menjadi persis seperti apa yang diinginkannya atau mirip dengan penyanyi lainya. Siti Chairani Proehoeman mengerti bahwa suara adalah suatu yang biologis dan sesuatu yang tidak dapat ditiru dan itulah yang Natasha sukai dari ajarannya, bahwa Siti Chairani Proehoeman mempelajari karakter seorang penyanyi sebanyak yang beliau bisa dan beliau mengajarkan mereka cara yang seharusnya diajarkan dan natsha merasa Siti Chairani Proehoeman memiliki telinga atau pendengaran yang baik juga dan dia tahu bagaimana melatih melalui suara dan dapat membuat 
penyanyi atau musisi yang lebih baik. Natasha harus menjadi seperti Siti Chairani Proehoeman yaitu menjadi seorang Mentor yang baik di sisi musik yang juga berarti bahwa Siti Chairani Proehoeman tahu cara membentuk Natasha melalui musik dan apa yang dia rasakan itu sangat special (Natasha Sass, wawancara 1 Juni 2018 di media sosial WA (Whats App) di German-Indonesia).

Menurut Iklil Jannah, cara Siti Chairani Proehoeman mengajar teknik vokal ialah dimulakan dengan Vokal warm up dan seterusnya menyanyi lagu yang telah diberikan. Siti Chairani Proehoeman menunjukkan phrasing nyanyian, pernafasan, dynamics, projection dan juga ayat yang sentiasa ucapkan ialah "think high" atau "think of E. Kesan saat belajar dengan Siti Chairani Proehoeman ialah yang pertama bukan mudah untuk menyanyi, yang kedua Iklil Jannah sangat terkesan dengan kesabaran beliau untuk mengajarnya yang sangat lemah dan mempunyai vocal nodule mengakibatkan kesukaran untuk menyanyi pada waktu itu, karena beliau seorang yang mempunyai banyak pengalaman untuk mengerti ataupun menganalisa suara atau teknik vokal pelajar -pelajarnya untuk dibaiki supaya lebih baik dan itu kekuatan yang ada pada beliau. banyak orang pandai bernyanyi tetapi bukan semua orang dapat ilmu teknik nyanyian dengan baik. itulah hakikatnya dan pada pendapat Iklil Jannah itu yang membedakan seorang penyanyi biasa dengan penyanyi yang berguru. Jadi , antara yang di peroleh sehingga menjadi penyanyi professional ialah ilmu, keberanian dan keyakinan diri serta semangat untuk melakukan muzik sebagai karier dan tidak semua guru vokal mampu melakukannya (Iklil Jannah, wawancara 2 Juni 2018 di media sosial WA (Whats App) di Malaysia-Indonesia).

Menurut Rahmiati adalah salah satu mahasiswa paling lama belajar dengan Siti Chairani Proehoeman di Institut Seni Indonesia Padangpanjang saat belajar dengan Siti Chairani Proehoeman saat belajar sangat disiplin tidak semua orang bisa mampu untuk belajar dengan disiplin karena rahmi sendiri mengakui tidak bisa untuk disiplin tetapi setelah belajar dengan Siti Chairani Proehoeman dia lebih mampu untuk mendisiplinkan dirinya dan beberapa contoh hal saat ujian dengan Siti Chairani Proehoeman adalah harus bisa membaca partitur lagu yang telah di berikan, dan setiap ujian wajib hafal lagu yang diberikan, dan di pertunjukan juga memaki kostum saat konser dan selaras dengan zaman lagu yang akan di nyanyikan seperti zaman barok sesuai dengan baju zaman barok, zaman klasik bajunya juga sesuai dengan baju klasik. Siti Chairani Proehoeman salah satu orang yang mampu menggali potensi yang ada di muridnya, beliau bisa meningkatkan percya diri muridnya saat bernyanyi. Semua ilmu yang berikan sangat berguna hingga saat ini (Wawancra Rahmiati Lubis, 13 agustus 2018 di Padangpanjnag).

Saat mengajar Siti Chairani Proehoeman menerapkan disiplin sesuai yang pernah di pelajari dan di alaminya saat kuliah di Eropa, tetapi tidak semua yang bisa menerima seperti Indonesia, muridnya mengaku bahwa pada waktu itu musik klasik merupakan hal yang baru yang pernah dipelajari di Indonesia khususnya di STSI
Padangpanjang, karena untuk memperkenalkan hal yang baru tersebut dan di sana murid Siti Chairani Proehoeman belum bisa menerima disiplin seperti yang diterapkan seperti di Eropa. Banyak yang tidak bisa untuk hidup disiplin karena merupakan hal yang baru dan segala sesuatu harus dilakukan perlahan agar bisa terbiasa untuk menjalani aktifitas atau pembelajran tersebut, walaupun semua yang dilkakukan adalah hal yang sangat baik bagi murid-muridnya, jadi ini merupakan kekerasan simbolik saat mengajar sesuai dengan penerapan yang pernah dilakukannya saat berada di negara lain atau tempat lain yang sudah biasa melakukan rutinitas seperti hal tersebut.

6. Paduan Suara

Saat setahun mengajar di ITM banyak murid yang ingin belajar dengan Siti Chairani Proehoeman dari Institusi dan privat, dalam keseharian Siti Chairani Proehoeman sangat sibuk, ia juga bekerja di Dewan Pustaka Dan Bahasa(balai pustaka) sebagai ahli dalam membuat inskolpedia dibidanag. Dan minta bekerja sebagai Voice Master untuk paduan suara SUARA MAS yang kelola oleh Penerbangan MAS. Tidak hanya itu banyak paduan sura yang telah di bentuki Siti Chairani Proehoeman saat berada di Malaysia.

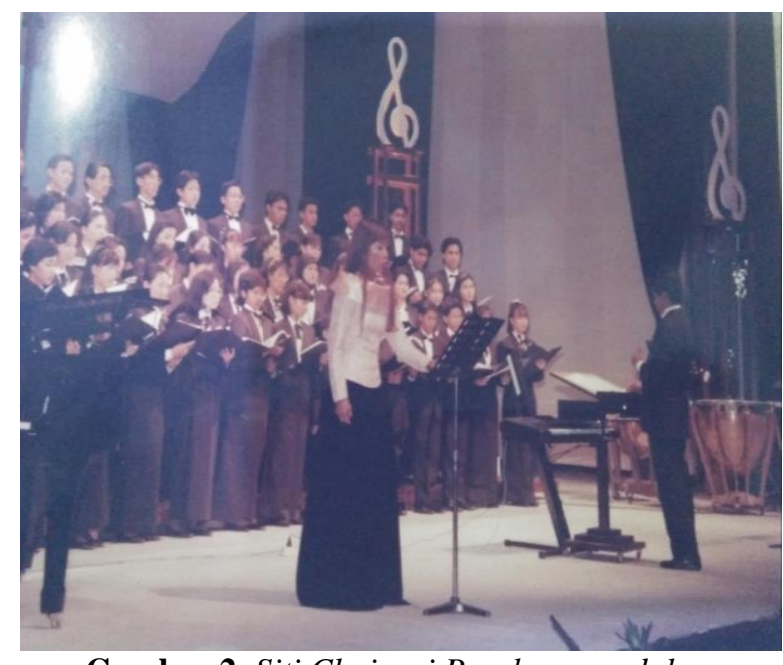

Gambar 2. Siti Chairani Proehoeman dalam persembahan diiringi Choir

(Dokumentasi: Siti Chairani Proehoeman repro oleh Ofa Yutri Kumala, 21 Juli 2018)

Salah satunya Koir Kebangsaan National Choir of Malaysia dan beliau menjadi direktur dan vokal master dan banyak konser yang telah dilakukan oleh konser yang dilakukan oleh koir kebangsaan yang dipimpin oleh Siti Chairani Proehoeman(Siti Chairani Proehoeman, wawancara 5 agustus 2018, di Jl. Kampung Talang no 15 Ganggo Hilia, Bonjol Pasaman). Koir kebangsaan terdiri dari: Children's Choir umur 5-11 tahun, Youth Choir umur 5-11 tahun, Madrigal Singers terdiri dan orangorang yang telah ahli dalam bernyanyi dan Full Choir terdiri dari semua anggota paduan suara Children's, Youth Choir dan Madrigal Singers. 


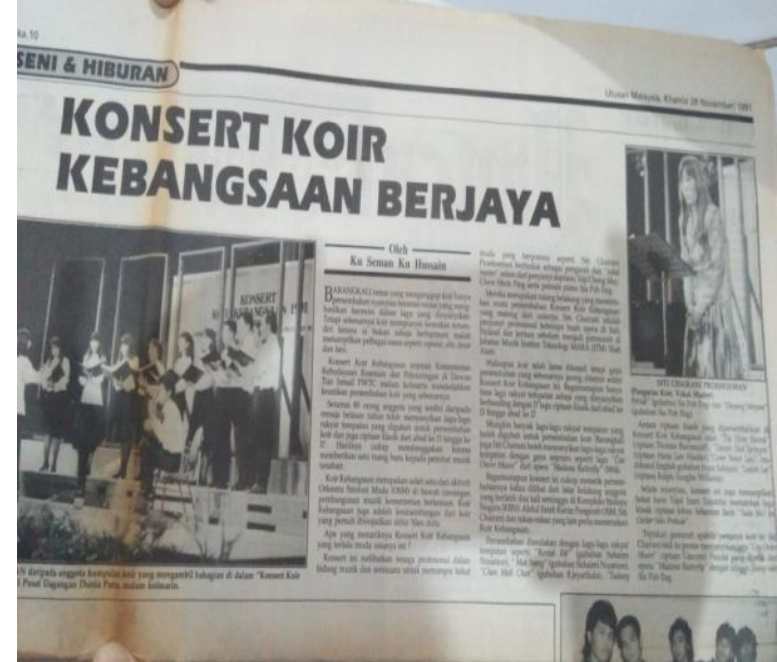

Gambar 3. Konser Koir kebangsaan Koran Utusan Malaysia kamis 28 November 1991

(Dokumentasi: Siti Chairani Proehoeman repro oleh Ofa Yutri Kumala, 21 Juli 2018)

Siti Chairani Proehoeman juga di minta mengajar di Korea Selatan sejak tahun 2007, belliau mengajar sebagai dosen di Busan University of Forign Studies Busan, South Korea sejaka 2001-2009.

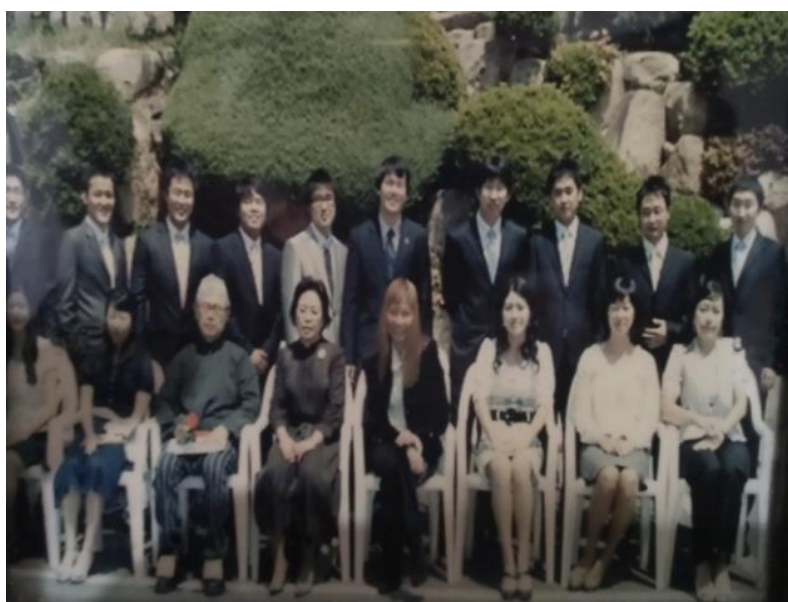

Gambar 4. Bersama dosen-dosen an University of Forign Studies Busan, South Korea

(Dokumentasi: Siti Chairani Proehoeman repro oleh Ofa Yutri Kumala, 21 Juli 2018)

Pada tahun 2009 Siti Chairani Proehoeman mengundurkan diri karena saat itu hanya bisa pulang $1 \mathrm{x}$ setengah tahun, di suruh kembali ke Indonesia agar lebih dekat dengan orang tua yang pada saat itu usia kedua orang tua 80-an, akhirnya Siti Chairani Proehoeman pindah kerja ke Malaysia yaitu di ASWARA, ASWARA adalah satu-satunya Institusi pengajian tinggi dalam bidang persembahan yang di dukung penuh oleh kerajaan Malaysia dibawah Kementrian Perpaduan, Kebudayaan, Kesenian dan Warisan Malaysia. Siti Chairani Proehoeman memilih kembalinke Malaysia dengan alasan agar bisa pulang ke Indonesia setiap minggu atau kapanpun ia inginkan karena bisa pulang untuk melihat orang tuanya yang sudah berumur 80 -an, tetapi saat mengajar d ASWARA (Siti Chairani Proehoeman, wawancara 5 agustus 2018, di Jl. Kampung Talang no 15 Ganggo Hilia, Bonjol Pasaman).

7. Kontribusi Yang Telah Diberikan Kepada Murid

Azizzul Haqim Md Anuwar. Graduan Muzik dari Aswara (Vokal). Dibimbing oleh Siti Chairani Proehoeman selama 4 semester ketika pengkajian. ia merupakan Juara bagi Kategori Irama Malaysia program 3 Juara anjuran TV3 Malaysia, dan Ia merupakan Juara 5 Rancangan D'Academy Asia 3 terbitan Indosiar, Indonesia. Kini Ia merupakan penyanyi serta merupakan guru vokal di beberapa institusi kerajaan dan juga swasta serta menjadi guru vokal di Prodigy Studio, Kajang Selangor (Azzizul Hakim, wawancara 28 Juni 2018 di media sosial WA (Whats App) di Malaysia-Indonesia).

Prof Siti Chairani Proehoeman adalah satu nama yang besar dalam industri didikan vokal khususnya di Malaysia. Sentuhan beliau keatas diri Jamilah telah berjaya membuatnya lebih matang dalam nyanyian, tidak takut lagi untuk menyanyi dengan percaya diri. Ia merasakan kejayaan dalam ajang ujibakat kemasukan ke Berklee College of Music juga disebabkan ilmu yang diberikan oleh beliau. Sehingga kini, ia masih mempraktikkan pengajaran beliau, tidak hanya dari segi teknik vokal, jenis latihan vokal dan apa-apa sekalipun, ia masih memegang utuh ilmu yang dicurahkannya kemana-mana pun Jamilah pergi. Kemudian ia akan terus ingat pesanan beliau untuk terus menuntut ilmu sehingga ke peringkat tertinggi. Dan jamilah sangat ingin menjadi orang seperti Siti Chairani Proehoeman (Jamilah Binti Abu Bakar, wawancara 17 Juni 2018 di media sosial WA (Whats App) di Malaysia-Indonesia).

Jamilah Binti Abu Bakar saat ini berusia 23 tahun, Pendidikan, Sijil Pelajaran Malaysia (10A), Diploma Muzik dari ASWARA (Pengkhususan Vokal Klasikal) CGPA: 3.81. Pelajar satu semester Ijazah Sarjana Muda di Berklee College of Music, Boston, USA. Sekarang sedang menyambung pengkajian di Universiti Pendidikan Sultan Idris, Perak dalam bidang Ijazah Sarjana Muda Pendidikan Muzik Dengan Kepujian.

Prestasi yang telah di raih oleh Jamilaah antara lain: Penerima Anugerah Dekan dan Anugerah Pelajar Terbaik sepanjang pengajian diploma muzik di ASWARA (2013-2016). Membuat konsert solo berjudul Konsert Sulaman Warisan pada tahun 2013 melalui program Mentor Mentee JKKN. Menerima kunjungan khas daripada Tun Dr. Mahathir Mohamad dan Tun Dr. Siti Hasmah yang amat menyokong karier nyanyian Jamilah. Membuat persembahan di pentas berprestij Dewan Filharmonik Petronas untuk Konsert Keroncong Kasih Menyusur Zaman pada tahun 2010. Pada tahun 2012, Jamilah dijemput sekali lagi untuk membuat persembahan untuk Konsert Keroncong Merdeka diiringi "Malaysian Philharmonic Orchestra" bersama penyanyi hebat Dato' Yusni Hamid dan Datin Paduka Julie Sudiro.

\section{Beberapa Pendapat Tentang Siti Chairani} Proehoeman

Rahmiati adalah salah seorang murid paling lama dan paling dekat dengan Siti Chairaani Proehoeman, 
sehingga kedekatannya dengan Siti Chairani Proehoeman seperti ibu dan anak, Siti Chairani Proehoeman adalah sosok yang disiplin, romantis, baik hati, penyayang, bersahabat, berwibawa dan mempunyai wawasan yang sangat luas. Saat belajar dengan Siti Chairani Proehoeman banyak ilmu yang di dapat oleh Rahmi, tidak hanya itu karena belajar dengan Siti Chairani Proehoeman, Rahmi banyak diterima tawaran kerja dan lulus di tempat kerja yang telah memintanya untuk mengajar karena semua ilmu yang diterapkan Siti Chairani Proehoeman sangat bermanfaat dan sangat di butuhkan oleh orang yang ingin beljar bernyanyi. (Wawancra Rahmiati Lubis, 13 agustus 2018 di Padangpanjnag).

Menurut Jamilah Binti Abu Bakar pada awalnya, pertama kali bertemu Prof Siti Chairani Proehoeman adalah pada ujibakat kemasukan ke ASWARA dan Prof Siti kelihatan begitu tegas dan serius. Tetapi setelah lama berada dalam bilik tersebut, Ia melihat Prof Siti boleh tersenyum, Ia menarik nafas lega. Prof bukanlah seorang yang serius sepanjang masa. Beliau adalah seorang yang baik dan penyayang. Setelah mengikuti kelas dengan beliau, beliau adalah seorang yang sangat penyayang, ikhlas dan mudah untuk berbicara (Jamilah Binti Abu Bakar, wawancara 17 Juni 2018 di media sosial WA (Whats App) di Malaysia-Indonesia).

Jamilah pernah mempunyai guru-guru vokal sebelum Prof. Dr. Siti Chairani. Antara lain adalah Wawang Wijaya yang khusus dalam bidang keroncong, Cikgu Siti Hajar dan Ludwig Van Medrano dari Filipina. Masingmasing mempunyai kelebihan dan cara mengajar yang tersendiri. Namun, Jamilah dapat belajar teknik vokal yang lebih mendalam lagi dari pada Prof Siti, di mana beliau menekankan kesediaan pita suara (vokal cord) sebelum menyanyi. Latihan suara yang beliau berikan cukup membantunya ketika melakukan persembahan nyanyian yang benar. Secara otomatis segala teknik yang diajarkan kepada Jamilah ketika persembahan tanpa perlu ia memikirkannya. Jamilah merasa otot suaranya mulai tidak tegang, ia lebih nyaman atau rilek ketika bernyanyi, yang paling penting adalah jamilah lebih merasakan bait-bait lirik lagu tersebut kerana di dalam kelas, Prof Siti sangat menekankan tentang kefahaman lagu. Jelas sekali tugas seorang penyanyi adalah untuk menyampaikan isi lagu tersebut, lalu interpretasinya sangat signifikan dalam kelancaran sesebuah nyanyian. (Jamilah Binti Abu Bakar, wawancara 17 Juni 2018 di media sosial WA (Whats App) di Malaysia-Indonesia).

Menurut Natasha Sass Kesan pertama tentang Siti Chairani Proehoeman adalah dia mencari siswa yang serius tentang apa yang ingin mereka lakukan, apa yang ingin mereka lakukan dan Natasha berfikir ketika beliau pertama kali bertemu dengannya, beliau mengatakan "apakah Anda benar-benar menginginkan ini (berlatih bernyanyi) atau melakukannya (bernyanyi) atau anda tidak menginginkan ini sama sekali tanpa benar-benar mengatakannya (hanya dengan gelagat atau gerak gerik tubuh) dan saya menyadari dia adalah seorang pelatih yang mereka inginkan dan di cari- cari dan harus memiliki nyanyian atau sesuatu yang bisa saya ambil (contoh) dengan sangat serius dan Natasha ingin seorang guru yang berada di pemikiran yang sama dengannya dan Siti Chairani Proehoeman memberikan kesan seperti itu pertama kali dia bertemu dengan Siti Chairani Proehoeman. Jadi Intinya Siti Chairani Proehoeman sangat serius ketika dia menjadi seorang guru, atau pelatih vokal (Natasha Sass, wawancara 1 Juni 2018 di media sosial WA (Whats App) di German-Indonesia).

Menurut Nurkholis salah satu murid Siti Chairani Proehoema, pandangan terhadap Siti Charani Proehoeman sebagai seniman Indonesia menurutnya beliau adalah seorang soprano yang sangat baik dan profesional, professional dalam aspek disiplin kemudian memberikan bahan-bahan yang belum pernah di kenal di indonesia. Siti Chairani Proehoeman tidak hanya bertahan di pertunjukan orkes klasik saja tetapi Nurkholis pernah melihat beliau dikarya komposisi orkes tradisi memainkan dendang minang dan di nyanyikan dengan cara teknik vokal klasik menrutnya ini merupakan suatu yang unik, Siti Chairani juga mengapresiasi musik jazz, pop dan lain sebagainya di lihat dari aspek kesenimanan. Walaupun beliau lebih dominan untuk musik-musik serius beliau terbuka atas banyaknya gendre musik beliau mau bergabung yang penting tujuannya positif, mempunyai prospek yang baik kedepan pada kesenimanan, kreatifitas untuk pendidikan dan bisa tranformasikan lewat kurikulum dan pembaruan-pembaruan dalam dunia kependidikan seni musik (Wawancara Nurkholis 16 Februai 2018 di Padangpanjang).

Siti Chairani Proehoeman mempunyai banyak referensi tentang berbagai macam ilmu. Nurkholis melihat Siti Chairani Proehoeman terlahir dari keluarga yang berpendidikan tinnggi dan orang-orang yang sangat besar peranannya di Indonesia maupun di luar Indonesia, disana membuat Siti Chairani Proehoeman mempunyai wawasan tinggi baik dari pergaulan karena kebiasaan dan hidup dikalangan orang orang yang hebat dari berbagai daerah bahkan negara lain. Siti chairani tidak pernah membeda-bedakan setiap kalngan sehinngga Nurkholis tidak ada merasakan jarak dengan beliau walaupun Nurkholis besar di kampung saja tiak sama dengan kehidupan Siti Chairani Proehoeman, bahkan beliau sangat support orang-orang yang berkemauan tinggi dan selalu berusaha (Wawancara Nurkholis 16 Februai 2018 di Padangpanjang). Siti Chairani adalah sosok seorang perempuan yang kuat, mempunyai kepercayaan diri yang besar, sosok seorang guru yang mempengaruhi eksistensi dalam karir muridnya. Muridmurid Siti Chairani apa bila mendengarkan kata-kata Siti Chairani pasti akan sukses(Nurkholis, Wawancara 16 februari 2018 di Padangpanjang).

\section{B. Kontribusi Siti Chairani Proehoeman dalam Mengembangkan Kesenian Indonesia}

Pengertian Kontribusi Kontribusi berasal dari bahasa inggris yaitu contribute, contribution, maknanya adalah keikutsertaan, keterlibatan, melibatkan diri maupun sumbangan. Berarti dalam hal ini kontribusi dapat berupa materi atau tindakan. Hal yang bersifat materi 
misalnya seorang individu memberikan pinjaman terhadap pihak lain demi kebaikan bersama. Kontribusi dalam pengertian sebagai tindakan yaitu berupa perilaku yang dilakukan oleh individu yang kemudian memberikan dampak baik positif maupun negatif terhadap pihak lain. Sebagai contoh, seseorang melakukan kerja bakti di daerah rumahnya demi menciptakan suasana asri di daerah tempat ia tinggal sehingga memberikan dampak positif bagi penduduk maupun pendatang. (Ahira, 2012 : 77. 20 21).

1. Kontribusi Sebagai Staf Pengajar di ASKI Padangpanjang

Pada tahun 1996 Siti Chairani Proehoeman pulang ke Indonesia. Mulai kuliah S3 di di Universitah Gadjah Mada (UGM), pada saat itu Siti Chairani Proehoeman pergi ke Akandemi Seni Karawitan Indonesia (ASKI) yang sekarang adalah Institut Seni Indonesia Padangpanjang (ISI) untuk mendapatkan data yang akan diteleti untuk S3 dan tiba-tiba sudah bisa mengajar di ASKI padangpanjang. Di ASKI Siti Chairani Proehoeman mengajar di jurusan Musik dan Jurusan karawitan.

Saat mengajar di ASKI padangpanajang Siti Chairani Proehoeman mengajar sebagai dosen luar bisa kususnya dibidang musik dan karawitan, Siti Chairani Proehoeman, mengajar vokal dengan muridnya yang paling lama adalah Rahmiati yang biasa dipanggil Rahmi, Rahmi merupakan murid yang mempunyai bakat bernyanyi yang bagus, saat belajar dengan Siti Chairani Proehoeman, beliau belajar dengan Siti Chairani Proehoeman kurang lebih 5 tahun sehingga hubunga beliau dengan Siti Chairani Proehoeman sangat dekat dan hari-hari Rahmi pada waktu itu selalu bersama Rahmi dan seperti orang tua sendiri, Siti Chairani Proehoeman sangat perhatian dan romantis walaupun sangat disiplin dan Rahmi sendiri mengaku tidak bisa mengikuti kedisiplinan hidup Siti Chairani Proehoeman, tetapi dengan disiplin itulah semua murid Siti Chairani Proehoeman berhasil dan menjadi orang-orang sukses( Wawancara Rahmiati Lubis, 12 Agustus 2018 di Padangpanjang)

Banyak kontribusi Siti Chairani Proehoeman yang telah dilakukan di ASKI Padangpanjang, dan saat itu banyak pertunjukan yang telah dilakukan di ASKI padangpanjang dan telah Tamppil di berbgai daerah dan sempat ke Malaysia bersama Yoebar Djaelani, Alek Wisnu Mintargo, Martarosa, Nursyirwan, Imal Yakin, Sastra Munafri, Bambang Wijaksana dan banyak lagi dosen yang terlibat dalam berbagai pertujukan dengan dosen dan mahasiswa Jurusan musik maupun karawitan. Berbagai pertunjukan seperti orchestra yang telah di sajikan diberbagai darerah tersebut dan menurut para dosen dosen ASKI saat wawancra saat latihan dengan Siti Chairani Proehoeman mereka mengaku sangat disiplin tiada hari untuk bermain saat konser akan dilaksanakan, semua dituntut untuk disiplin dalam latihanan karena sering latihan semua pemain hafal dengan lagu yang di nyanyikan Siti Chairani Proehoeman, siang malam selalu latihan di kampus sehingga pertunjukan yang di sajikan menjadi baik dan sempurna (Wawancara Bambang Wijaksana, Martarosa, Imalyakin, Nursyirwan pada 16 Juni 2018 di Jurusan Musik ISI Padangpanjang).

Sebagian foto saat konser bersama Siti Chairani Proehoeman dengan konduktor Martarosa di jambi Repertoar yang berjudul Ah Pervido dengan Serambi orchestra STSI padangpanjang antaralain sebagai berikut:

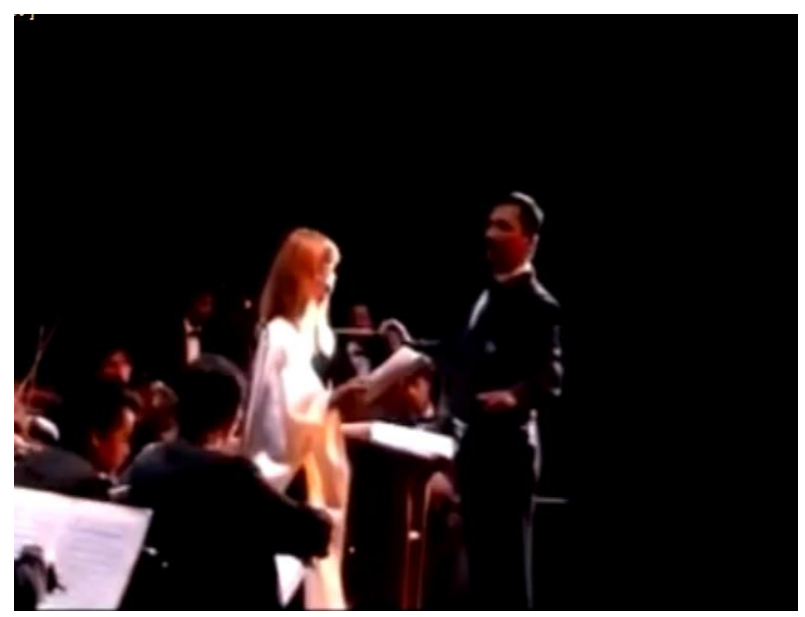

Gambar 5. Konser bersama Serambi Orkestra STSI Padangpanjang

(Dokumentasi: Repro dari dokumen Martarosa capture di ambil dari Vidio saat pertunjukan )

Siti Chairani juga mengajar di Jurusan karawitan dan diminta untuk membuat kurikulum mengenai sasaran efesiensi dan produktifitas dan meningkatkan standar Pendidikan Seni Pertunjukan di Jurusan Karawitan, dan pada saat itu Siti Chairani Proehoeman sedang peneltian untuk tesis S3 di UGM. Siti chairani juga mengajar tetantang vokal dendang darek secra fisiologi yang benar terkait dengan penelitian yang sudah dilakukannya, Gaya bentuk musikal tradisional dendang darek dapat dipelajari, sama seperti setiap gaya bentuk musik lain yang dapat dipelajari. Sedangkan interpretasi penyajian gaya musik adalah suatu kontribusi pribadi yaitu bakat dan struktur anatomi yang merupakan tekstur personalitas sebagai sumber tekstur tonal nya. Salah satu contoh dari hasil eksperimen yang dilakukan, sebagai model eksperimen adalah tiga alumni jurusan karawitan STSI Padang Panjang mendendangkan repetoar dendang darek yang sama. Salah satu di antaranya telah menjalani training vocal selama satu semester di tahun 2000. Pendendang berlatar training vocal selama satu semester menyatakan mampu berdendang lebih baik, lebih mudah ketika masih dalam periode training, ternyata sekarang telah mengalami permasalahan vocal, dan proses bernyanyi tidak semudah seperti dulu oleh karena memang tidak melakukan training vokal lagi. Si pendendang menyatakan berdasarkan pengalamannya, bahwa training vokal selama satu semester tidak cukup untuk memperoleh basic singing skill (Proehoeman: 2006).

Hasil-hasil eksperimen membuktikan bahwa, teknik vokal yang tepat dapat dipelajari melalui proses 
pembelajaran untuk memperoleh cara menyanyi yang efisien dan kondisi patologis yang sehat, yang berbeda dari cara menyanyi tradisional dendang darek yang didasari oleh natural habit yang tidak selalu naturally correct. Apabila permasalahan vokal muncul tanpa penanganan yang tepat, maka kondisi tersebut menjadi suatu faktor yang merugikan diantara para pendendang. Adapun alternatif pengembangan cara bernyanyi yang sesuai dengan kaedah-kaedah fisiologi yang ditawarkan terhadap cara bernyanyi tradisional dendang darek adalah langkah yang baru melalui langkah pendekatan ilmiah yang sebelumnya mungkin belum pernah diaplikasikan untuk disiplin literature musik etnis di jurusan karawitan dimanapun jua. Namun demikian disertasi ini secara khusus diteliti dan disesuaikan berdasarkan kompas vokal dan tingkat kesulitan literature musik vokal tradisional dendang darek yang berkemungkinan bisa dimamfaatkan diwaktu yang akan datang sebagai salkah satu upaya memperoleh cara menyanyi yang tepat, efisien dan sehat. Alternatif pengembangan cara menyanyi yang sesuai deng kaedahkaedah fisiologi merupakan langkah baru dan vital sebagai salah satu upaya pemeliharaan dan dpengembangan cara menyanyi tradisional dendang darek khusunya dan seni musik tradisional minangkabau pada umunya. (Proehoeman: 2006).

\section{Mendirikan Sanggar SCP Teater}

Chairani Proehoeman membuat sanggar seni yang bernama SCP Teater yang nama itu adalah singkatan dari namanya Sendiri yaitu Siti Chairani Proehoeman. Disana konstribusi yang dilakukan adalah mengembangkan musik musik tradisional minangkabau dan melakukan penelitian tetang musik-musik Etnis yang berada di Minangkabau hal-hal yang dilakukan sebelumnya melakukan research atau peneltian terlabih dahulu dan megundang msuik etnis Minangkabau ke SCP teater untuk di pertunjukan, mayoritas penonton adalah turis asing tetapi tidak tertutup untuk domestic masyarakat Indonesia, sebelum pertunjukan dilaksanakan semua deskripsi tentang musik itu sendiri di transkipkan dari segala macam bahasa, dari berbagai penonton yang ada di bermacam-macam negara (Wawancara I Dewa Nyoman Supenida, 9 februari 2019).

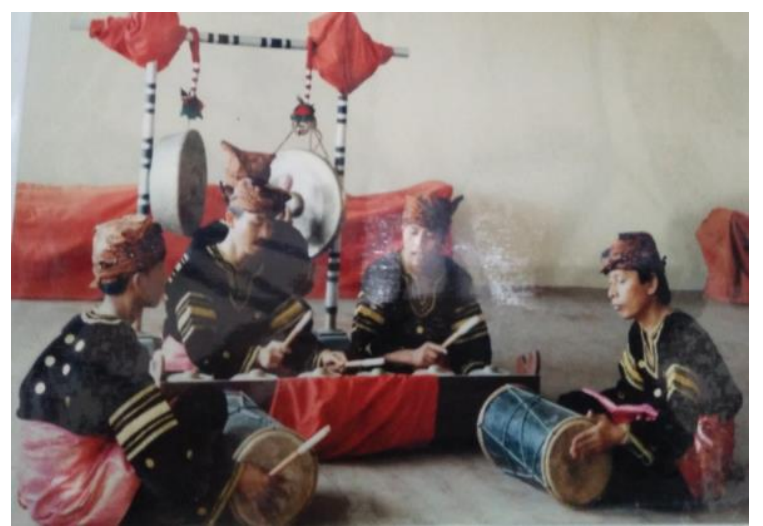

Gambar 6. Talempong Unggan di SCP teater (Dokumentasi: Siti Chairani Proehoeman repro oleh Ofa Yutri Kumala, 21 Juli 2018)
Sangat banyak hal yang dilakukan SCP teater pada saat itu untuk menggali kembali kesenia n-kesenian asli minangkabau yang tidak diketahui sama semua orang dan selalu melakukan penelitian dan melakukan pertunjukan kesenian tersebut dan di SCP teater, dan membawakan langsung informan dan pemusik asli etnis yang telah diteliti tersebut untuk dipertunjukan di SCP teater(Wawancara I Dewa Nyoman Supenida, 9 februari 2019).

SCP teater mengalami penurunan yang pada saat itu para turis asing banyak yang pulang kenegaranya masing-masing karena pada saat itu Indonesia sedang mengalami krisis pada zaman pemerinthan orde baru. Sehingga penonton pertunjukan tersebut sudah mulai sepi karena penikmatnya adalah para turis asing. Siti Chairani Proehoeman pada akhirnya memutuskan untuk menutup SCP Teater.

3. Menambahkan repertoair seriosa Indonesia dalam konser yang pernah dilaksanakan di luar negeri

Berdasarkan data yang sudah di dapat Siti Chairani proehoeman selalu menambahkan repertoar seriosa ke dalam setiap konsernya seperti contoh lagu yang pernah dibawakan saat konser di berbagai negara, Siti Chairani Proehoeman juga menjadikan lagu seriosa sebagai bahan mata kuliah di universitas di Malaysia, aebagian contoh repertoar seriosa yang dijadikan repertoar saat konser antaralain sebagai berikut: Puisi Rumah Bambu, Derita, Senyum Dalam Derirta, Disela Rumput Hijau.

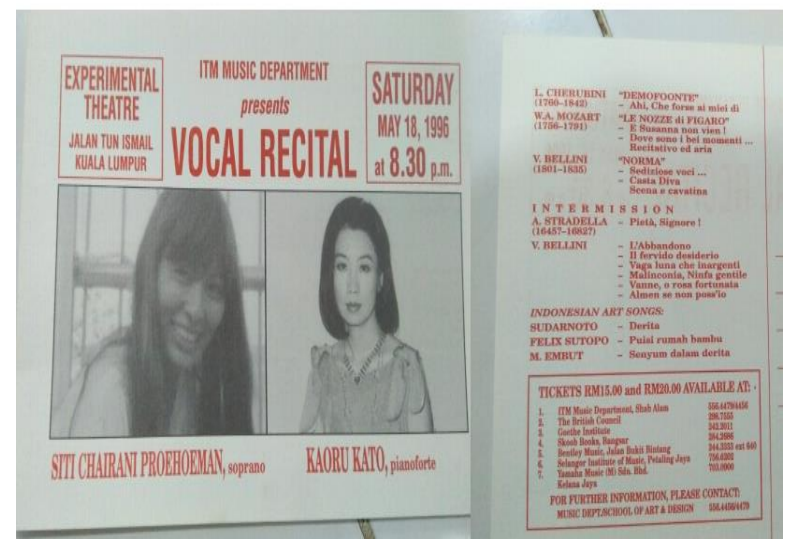

Gambar 7. Salah satu pamphlet Siti Chairani repertoar Seriosa

(Dokumentasi: Siti Chairani Proehoeman repro oleh Ofa Yutri Kumala, 20 Juli 2018)

Siti Cahirani Proehoeman menambahkan repertoar seriosoa kedalam konsernya dengan alsan beliau sangat mengagumi lagu sriosa Indonesia, lagu seriosa adalah lagu yang sangat bagus dan saat penonton yang tidak tau dengan seriosa Indonesia memberikan antusia yang sangat bagus saat menampilkan seriosa Indonesia, Siti Chairani tidak hanya di Malaysia untuk menambahkan repertoar seriosa tetapi juga di Eropa. (Siti Chairani Proehoeman, wawancara 19 Juli 2018, di Jl. Kampung Talang no 15 Ganggo Hilia, Bonjol Pasaman).

\section{Kesimpulan}


Merajuk pada musikologi musik sebagai dasar ilmu pengetahuan musik umum dan konvensional dari dulu hingga saat ini, ditujukan melalui penjelasan biografis serta melalui tinjauan sejarah perjalan karir Siti Chairani Proehoeman sebagai penyanyi soprano maka dapat ditarik kesimpulan bahwa mengapa Siti Chairani Proehoeman terkenal di luar negeri yaitu karena dari kecil sudah di ajarkan dengan displin musik oleh orang tuanya dari lingkungan keluarga yang bergaul dengan orang luar negeri pada zaman itu, dan semua kebiasaan dalam bergaul dengan orang-orang asing di berbagai negara yang biasa mendisiplinkan belajar musik dari kecil, dan keturunan yang bisa bermain musik.

Faktor faktor yang mempengaruhi Siti Chairani terkenal di luar negeri adalah faktor pendidikan orang tua yang selalu mendatangkan beberapa guru yang ahli di berbagai bidang musik. Selain itu Siti Chairani Proehoeman setelah lulus SMA sudah pindah ke Eropa dan berkuliah di sekolah musik terkenal di dunia yaitu Conoservatorio Di Musika Di Canta Cecillia yang sangat disiplin di bidang musik dan tidak semua orang yang mudah dan bisa masuk ke sana karena biaya yang sangat mahal. Walaupun Siti Chairani Proehomean adalah latar belakang keluarga yang berperekonomian mampu, tetapi Siti Chairani Proehoeman saat masuk di sekolah Concervatorio Di musika Di Canta Cecillia dengan prestasi yang dimilikinya melaui beasiswa.

Siti Chairani Proehoeman fokus dalam segala hal yang perlu untuk karir dan dirinya sendiri, dari berbagai pengalaman yang pernah dilakukan beliau adalah sosok yang sangat disiplin sehinnga semua hasil dari pencapaiannya untuk menjadi seorang soprano yang terkenal tidak setengah-setengah disitulah Habitus, Arena dan Modal yang telah menjadi pisau bedah dari penbeltian ini berdasarkan faktor keluarga, pendidikan, pergaulan, lingkungan, tempat tinggal dan kebiasaan dari kecil hingga sekarang yang masih dilakukan Siti Chairani Proehoeman yang menjadikannya salah seorang penyanyi soprano terkenal. Semua pencapaian itu dilakukan dengan kemauan keras dan bersungguhsungguh dalam proses kehidupan, menjadi manusia yang selalu ingin tau, belajar untuk mendapatkan hasil yang memusakan, satu lagi kata kuncinya adalah hidup disiplin.

\section{Daftar Pustaka}

Adam, Boestanul Arifin dan Kamal Zahara. 1985. "Pengantar Sejarah Musik. (Diktat Musik Aski Padangpanjang)". Padangpanjang: ASKI Padangpanjang,

Anne Ahira, Terminologi Kosa Kata, Jakarta: Aksara.

Ayurizal. 2015. "Fenomena Yoesbar Djaelani Sebagai Tokoh Musik Indonesia (Sebuah Biografi)". Padangpanjang: Institut Seni Indonesia Padangpanjang.

Brown, Radcliffe. 2006. "Metode, Teori, Teknik, Penelitian Kebudayaan” Yogyakarta: Pustaka Widyatama.
Harker Richard, Mahar Cheelen, Wilkes Chris. 1990. “Habitus x Modal+ Ranah= Praktik". Yogyakarta: Jalasutra.

Jenkins, Richard. 1992. "Membaca Pikiran Pierre Bourdieu” Routledge, London: Kreasi Wacana.

Leedy. 1997. Practical Research: Planning and Design. New Jersey: Merril-Prentice Hall.

Katamsi, Aning dan Zen Hae. 2011. "Pedoman Pelafalan Seriosa Indonesia”. Buku. Jakarta: KPG Kepustakaan Populer Gramedia.

Martarosa. 2016. “Apropriasi \& Estetika Musik Gamat” Jurnal volume 17 No. 11 April 2016

Martarosa. 2016. The History and development of Gamat Music a Prototype of Bandar Art In the West Sumatera Coalstal Area (Pesisir). Jurnal Humaniora, No 1 Februari 2016: 67-68

Miles, Matthew B. 1992. "Analisis data Kualitatif". Jakarta: UI-Pers.

Moleong, Lexy J. 1989. Metode Penelitian Kualitatif, Bandung : Rosdakarya

Mohammed, Sharifah Faizah Syed. 2016."The History and Development of Lagu Seriosa in the Context of Musical Nationalism in Indonesia". Australia: Monash University.

Nurkholis. 2012 "Lagu Seriosa Sebagai Lagu Seni Indonesia Pengaruh Musik Barat dan Musik Etnis Nusantara". Padangpanjang: Institut Seni Indonesia Padangpanjang.

Nyoman. 2010. "Metode Penelitian Kajian Budaya dan Ilmu sosial Humaniora Pada Umumnya”. Yogyakarta: Pustaka Pelajar Yogyakarta.

Proehoeman, Chairani Siti. 2006. "Dendang darek: Alternatif Pengembangan Cara Bernyanyi Tradisional ke Cara Yang Sesuai Dengan Kaedah Fisiologi”. Disertasi. Yogyakarta: Universitas Gadjah Mada Yogyakarta

Sjamsuddin, Helius1996 "Metodologi Sejarah". Yogayakarta: Ombak

Sutrisno, Mudji. 2005. "Teori-Teori Kebudayaan”. Yogyakarta: Kansius

Zon, Fadli 2013. "Idris sardi Perjalanan Maestro" Dubia, Jakarta: Fadli Zon Library, 2013. 